\title{
Interpersonal Trust and Mutually Beneficial Exchanges: Measuring Social Capital for Comparative Analyses*
}

\author{
PETR MATĚJŮ, ANNA VITÁSKOVÁ** \\ Institute of Sociology AS CR, Prague
}

\begin{abstract}
There are at least two significantly different approaches to the conceptualisation of social capital. Advocates of the most influential stream define social capital primarily as an attribute of societies, as an innate characteristic of the social environment based on the high degree of interpersonal and institutional trust facilitating people's co-operation. Adherents of the other stream define social capital in terms of mutually beneficial exchanges based on social connections and informal networks allowing individuals to achieve their own particular goals. The former approach prevails in 'western' countries, while the latter one prevails in the study of social change in post-communist societies where social capital drawing from interpersonal trust seems to be rather low. The aim of this article is to contribute to the conceptualisation and measurement of social capital, with a special emphasis on its role in post-communist societies. The authors attempt to develop a measurement model for the two distinct dimensions of social capital mentioned above. The measurement model for the two dimensions of social capital is developed and tested by confirmatory factor analysis. The authors proceed by testing the hypothesis that social capital defined as trust is only weakly linked to social stratification, while social capital defined as a person's involvement in mutually beneficial exchanges shows significant variation between groups defined by relevant stratification variables. The analysis was performed on the data from the Social Networks survey carried out in the Czech Republic in 2001 under the International Social Survey Programme.
\end{abstract}

Keywords: social capital, trust, social networks, mutually beneficial exchanges, stratification variables

Sociologický časopis/Czech Sociological Review, 2006, Vol. 42, No. 3: 493-516

\footnotetext{
* Work on this paper was made possible thanks to the support of the Grant Agency of the Czech Republic, Grant No. 403/03/340, for the project 'Economic, Social and Cultural Sources of Educational Inequalities and the Determinants of Life Success: Stage One in a Longitudinal Study' (first author) and to the support of the Ministry of Labour and Social Affairs, Grant No. 1J 005/04-DP2 ‘Unequal Access to Education: The Extent, Sources, Social and Economic Consequences, Policy Strategies' (second author). The first draft of the paper was presented at a meeting of the ISSP in Mexico City.

${ }^{* *}$ Direct all correspondence to: Petr Matějů or Anna Vitásková, Department of the Sociology of Education and Stratification, Institute of Sociology AC CR, Jilská 1, 11000 Prague 1, Czech Republic, e-mail: petr.mateju@soc.cas.cz. anna.vitaskova@soc.cas.cz
}

(C) Sociologický ústav AV ČR, Praha 2006 


\section{Introduction}

Some forty years ago, the role of human capital was recognised alongside physical capital as a major factor contributing to economic output. Though the idea has been around for decades that social relationships and networks play an important role in economic success at both the micro and macro level, the concept of social capital only originated in the 1970s, in the work of Glenn Loury [1977], who objected to the narrowly defined understanding of human capital in neo-classical economic theory. It was not until the 1980s, however, that Pierre Bourdieu [1985] and James Coleman [1988] successfully brought social capital to the wider attention of the social sciences.

Like the pioneering scholars in the field of human capital, who started out with loose measurement instruments and somewhat weak conceptual models that were designed to assess the contribution of human capital to economic growth, the well-being of nations, and the life-success of individuals, the proponents of social capital have gradually realised that the explanatory power of the models developed to examine the role of social capital depends not only on their complexity and sophistication but also on the validity, robustness (reliability), quality and comparability of the indicators used to measure the variations in social capital among nations in sociological and statistical surveys. We are evidently at the very beginning of this process.

Though there has been an enormous effort on the part of individual scholars [e.g. Putnam 1993, 1995, 2000a, 2000b; Portes 1998; Woolcock 1998, 1999, 2000; Woolcock and Narayan 2000; Narayan 1995, 1997, 1998, 1999; Narayan and Cassidy 1999] and institutions (e.g. World Bank, EBRD, OECD) to demonstrate the concept's potential for understanding differences in economic growth between nations and in the life-success of individuals, true cross-national and 'cross-system' comparative research in this area is still in its initial stage.

The aim of this article is to contribute to the conceptualisation and measurement of general social capital, with a special focus on post-communist societies in East-Central Europe. We assume that in these societies social capital operates in specific historical and social circumstances, and we will attempt here to develop a measurement model for two distinct dimensions of social capital: one defined primarily as an attribute of societies that facilitates people's co-operation; the other as the capacity of an individual to participate in informal networks based on mutually beneficial exchanges. From this perspective we propose a new measurement instrument for further analysis of the effects of stratification variables in the economic and institutional development of post-communist countries.

\section{The conceptualisation of social capital}

Social capital can broadly be defined as a network of social relations based on a variety of forms of 'trust' and 'reciprocity' that can lead to a wide range of private and public outcomes. This simple definition serves a number of purposes, but most im- 
portantly it draws attention to the 'sources' of social capital (i.e. the network of social relations) and their 'origins' (i.e. norms of trust, reciprocity, participation, cooperative behaviour), and it highlights the theoretical and empirical complexity of a construct that has received widespread attention from sociologists, political scientists, and economists.

Irrespective of disciplinary focus, however, the formulation of a consistent theory of social capital continues to be complicated by the existence of two different yet equally useful and theoretically rewarding conceptual and methodological approaches:

a) Social capital defined as mostly an 'attribute of an individual', as a person's potential to activate and effectively mobilise a network of 'social connections' based on 'mutual recognition' of proximity (in a social space) and maintained by symbolic and material 'exchanges' (Bourdieu). In this context, social capital has the properties of a 'private good', which individuals accumulate and use to achieve their own goals and personal advancements.

b) Social capital defined as mostly an 'attribute of a society', as a quality of networks and relationships enabling individuals to 'co-operate' and act collectively (Putnam). Within this framework, social capital is based on a high degree of interpersonal 'trust', as well as on the 'trustworthiness' of the public and political institutions that establish and uphold the 'rule of law', making all kinds of exchanges transparent and safe. For these reasons, social capital has the properties of a 'public good', facilitating the achievement of higher levels of efficiency and productivity; hence this form of social capital is often associated with economic growth.

Once the construct of social capital is distinguished from its outcome(s), it becomes even more obvious that there are several major difficulties in reconciling the above-mentioned conceptual approaches to social capital, which consequently affect measurement. First of all, it appears that economists, who search primarily for factors that account for differences in economic growth and the economic wellbeing of nations, often tend to prefer Putnam's interpretation of social capital as a public good, while sociologists, who strive to explain the reproduction of inequality, are more inclined towards Bourdieu's and Coleman's conceptualisation of social capital as a private good. Though there are exceptions to this rule, as far as measurement through proxy variables is concerned, economists are more likely to use the level of trust and social participation, while sociologists apply variables assessing a person's social esteem (prestige) and his/her position in power structures and involvement in informal networks and exchanges. This depends largely and independently on whether or not a particular approach is elaborated or applied in empirical research in either advanced capitalist, transitional or developing countries. Needless to say, neither of the two measurement strategies is satisfactory.

Second, most of these studies aim at investigating a specific life domain, such as civic, political or social engagement, or the size of networks, etc., which provide fragmentary information about the distribution of social capital [Van Der Gaag and 
Snijders 2005]. The distribution of social capital as either a private or a public good consequently affects the access and use of such social capital in attaining certain goals [Lin and Dumin 1986]. Therefore, social capital is context-specific in the production of returns.

Third, there is another issue that makes measurement rather difficult; namely, the difference between the wealthy societies of North America and Western Europe and the countries emerging from a communist past (hereafter 'transforming' societies). Grief's categorisation of institutional restructuring indicates that developed countries with well-established institutions and a high level of generalised or interpersonal trust and co-operation in achieving 'common goals' may contribute to the explanation of economic performance and growth of a relatively stable society [Grief 1994]. The explanatory power of such a construct decreases when applied to transforming societies whose institutional restructuring is often characterised by the existence of corruption, state failure, and the existence of a grey economy (i.e. negative social capital), accompanied by a low level of generalised trust [Grief 1994].

\section{Does the 'synergy view' offer a solution?}

There have been attempts to solve the problem of duality in the conceptualisation of social capital. In the 'synergy view of social capital', Woolcock refers to 'bridging' and 'bonding' social capital. 'Bonding social capital' (also known as 'defensive' social capital) is generated by strong, close ties between individuals, which allow them to meet their basic needs in the face of negative externalities. These strong ties are most often formed within families, clans, or close groups of neighbours. They mainly serve as a 'backup' to the members of such groups, for instance, providing food or money if a member is laid off.

'Bridging social capital' (also known as 'offensive' social capital) is defined by large groups of people that exist at various levels of society. These groups (most often taking the form of professional organisations and associations) work to further the goals of their members, often helping them to find jobs or helping to increase the dispersion of knowledge within such organisations, allowing members to achieve their goals and improve their socio-economic status.

Woolcock's view of social capital offers a plausible theoretical solution. However, the problem of different approaches to measurement remains. In order to begin any cross-national comparative work we must be able to develop measurement strategies for two distinct forms of social capital - one operating beyond the reproduction of inequality and the strategies that individuals and families develop in order to succeed in life (particularly during times of social change), the other explaining why in some societies people co-operate more easily and more effectively than in others. This is a fundamental problem that must be discussed before we turn our attention to the 'cultural problems of measuring social capital'. Deeper dimensions and fine-grained problems of measurement will emerge once we begin to formulate 
questions and items for questionnaires. However, this stage of comparative research still appears to lie well ahead of us.

\section{Social capital in transforming societies}

Many scholars argue that socialism destroyed the most important norms of trust: institutional (i.e. the basic trust in formal institutions of governance) and generalised trust (i.e. the extent to which people trust their fellow citizens). For instance, Kunioka and Woller [1999] examined the power of social capital in the democratic transition in Eastern Europe and postulated the dictatorship theory of missing social capital, according to which dictatorship destroys both forms of trust. After the collapse of a dictatorship, the remaining 'negative social capital' inhibits institutional and economic development. Simply put, the prevalence of negative social capital is not conducive to the development of generalised trust, and the lack of generalised trust hinders economic growth [Paldam and Svendsen 2001].

In addition, the deep changes in the social structure in transforming countries, accompanied by increasing socio-economic inequality, drew the attention of scholars to other mechanisms that also generated changes in social stratification and inequality: social mobility (especially towards economic and political elites), growth of income and wealth differentiation, changes in factors determining life-success, etc. The theory of various forms of capital has therefore also been applied within a different context and research framework.

Eyal, Szelényi and Townsley [1998], who made one of the most important contributions to the research on the post-communist transformation, argue, for example, that pre-communism, communism, and post-communism are three different stratification regimes, defined by the dominance of different types of capital. Postcommunism, in their view, is a historically unique system of stratification in which cultural capital (represented by higher education, providing a person with greater flexibility) is dominant. However, the transition to post-communism involves quite a complicated shift from the socialist rank order system, in which social capital, institutionalised as political capital (represented by a person's position in the Communist Party hierarchy), is dominant, to capitalist class stratification, where economic and cultural capital play strategic roles in the life-success of individuals [Eyal, Szelényi and Townsley 1998].

Like other scholars of social stratification in transforming countries, Eyal, Szelényi and Townsley [1998] argue that during a transition people tend to convert devalued forms of capital into new, more valued forms. This is the way that individuals prefer to cope with changes in the social structure. 'In a post-communist transition, for example, those who are well endowed with cultural capital may be able to convert their former political capital into informal social networks, which can then be usefully deployed to take advantage of new market opportunities' [ibid.: 7]. Table 1 depicts the role of different forms of capital in different types of societies. 
Table 1. Determinants of social structure in different types of societies

\begin{tabular}{|c|c|c|c|}
\hline \multirow[b]{2}{*}{ Type of Societies } & \multicolumn{3}{|c|}{ Type of Capital } \\
\hline & Economic & Cultural & Social \\
\hline $\begin{array}{l}\text { Baseline model 'ideal type' } \\
\text { of modern capitalism }\end{array}$ & +++ & ++ & $\begin{array}{c}+ \\
\text { (Rational social } \\
\text { network) }\end{array}$ \\
\hline $\begin{array}{l}\text { Pre-communist Eastern Europe } \\
\text { (before 1949) }\end{array}$ & ++ & ++ & 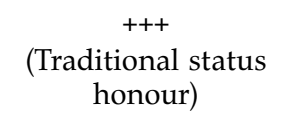 \\
\hline $\begin{array}{l}\text { Classical (Stalinist) model of socialism } \\
\text { (mid 1949s - mid 1960s) }\end{array}$ & - & + & $\begin{array}{c}+ \\
\text { (Institutionalised as } \\
\text { political capital) }\end{array}$ \\
\hline $\begin{array}{l}\text { Reform model of socialism } \\
\text { (mid 1960s - 1989) }\end{array}$ & + & ++ & $\begin{array}{c}+ \\
\text { (Institutionalied as } \\
\text { political capital) }\end{array}$ \\
\hline Post-communism (1989 - & ++ & +++ & $\begin{array}{c}+ \\
\text { (De-institutionalised } \\
\text { and rationalised } \\
\text { as social networks) }\end{array}$ \\
\hline
\end{tabular}

Note: Economic capital: economic and financial assets; Cultural capital: education and skills; Social capital: participation in various kinds of networks.

Source: Eyal, Szelényi and Townsley [1998: 23].

Other analyses based on comparative surveys [Eyal, Szelényi and Townsley 1998; Hanley, Matějů, Vlachová and Krejčí 1998] have corroborated the hypothesis that the real beneficiaries of the transformation are those who have been able to effectively combine the accumulated political capital of the past (nomenklatura cadres, communist technocrats) with cultural capital (education, knowledge). ‘Political capital' makes it possible to build social networks and maintain useful ties (social capital). 'Cultural capital' leads to greater flexibility and a better capacity to put all these assets to work under new circumstances.

It should be clear from what has been said above that in transforming societies the concept of social capital is one of the key issues for research. It aims to understand the process of social change and its consequences for people's career mobility and life chances, while in advanced countries, the same concept, though defined differently, is used to contribute to the explanation of cross-national variance in economic growth and overall well-being.

Therefore, the debate on measurement strategies for social capital should begin with an elaboration and the operationalisation of the two different concepts of social capital (as an attribute of individuals and a factor determining life-success vs. as an attribute of societies facilitating co-operation and contributing to economic growth), each drawing from different socio-economic and political environments and circumstances and thus focusing on different processes, relationships, and out- 
comes. The context cannot be isolated from the measurement of social capital. Omitting this important aspect when building measurement strategies, particularly in transforming societies, could result in potentially very strong explanatory variable(s) being concealed, while theoretically (and historically) less grounded variables with potentially less explanatory power are measured. Finding a solution to this problem should in fact precede the debate on the cultural dimension in the measurement of social capital, which of course also requires attention.

\section{Measurement strategies applied in transforming societies}

There is a general agreement that, at least at this stage, social capital can only be measured indirectly, through either distal or proximal indicators. The distal indicators refer to the outcomes of social capital that are not directly related to its key components (e.g. life expectancy, health status, crime rates, participation rates in tertiary education, family income, job growth) [Stone 2001]. Conversely, the proximal indicators are directly related to the major concepts of social capital, such as trust, reciprocity, and participation. In almost all research on social capital, the measurement of various levels and dimensions of trust and community participation prevails in some form. This has been the case of the majority of comparative surveys carried out both in advanced and transforming countries. This fact determines which research questions can be addressed by analysis.

As far as transforming societies are concerned, there are only a few empirical studies focusing on social capital and its role in economic growth. Rose [1998a, 1998b] and O'Brian [1998] have studied social capital in Russia to show the role of informal networks in the development of the strategies people require to cope with a social system in which formal organisations fail to operate fairly. In such a situation, the position of an individual in a given social hierarchy is one of the most important factors in obtaining necessary services. Only a few members of the lower classes are thus capable of obtaining much-needed goods and services. Since bribery is a fact of life in Russia, one can never be sure that one is not going to be out-bribed by one's neighbour for some necessary service [Rose 1998a].

O'Brian also attempts to determine what strategies are used by Russians when faced with negative externalities (a shortage of elementary goods and services, a paralysed market, pervasive corruption, etc.) and to what extent they participate in community-wide activities. His survey is constructed to provide data on the levels of trust between individuals and the varying levels of social networks. His study shows that failing infrastructure systems in the Russian countryside have pushed individuals towards closer family ties. And since the government is not taking any direct action to create functional social institutions in these areas, informal co-operation among villagers remains the key coping strategy. Despite the fact that there is evidence that stronger bridging social capital would benefit these villagers greatly in the form of increased access to markets, they would rather concentrate on their 
profit-making enterprises than risk expending energy to a attain a common good and receive nothing [O'Brian 1998].

Russia is certainly an extreme case among the transforming countries. With regard to East-Central Europe, in a study titled 'Social Capital in Transition: A First Look at the Evidence', Raiser, Haerpfer, Nowotny, and Wallace [2001] addressed the role of social capital in economic growth based on recent comparative surveys. They use a variety of measurements to determine the levels of social capital in transforming societies and to show how the available primary data sources ${ }^{1}$ can be used to address the question of the role of social capital in economic growth. Their analysis is limited by the fact that each of these surveys measures a different aspect of trust and form of social participation. By combining slightly different views of the three data sets, the researchers build groups of indicators and test their robustness and potential biases. Given that their sets of indicators allow for measuring either the formal or the informal dimension of social capital based on trust and social participation, the main results of the analysis contribute to the debate on the role of formal and informal social capital in economic growth. The lack of indicators for participation in networks based on mutually beneficial exchanges prevented them from addressing the role of this particular type of social capital in the transformation of the social structure and the determination of life-chances.

As far as the principal findings are concerned, by running a series of regressions, the authors found that there is no aggregate correlation between the level of anonymous trust (trust between two individuals who do not know each other) and the GDP growth of a particular country. This result contradicts the conclusions from studies focused on developed Western countries. The analysis reveals, however, that civic participation is positively correlated with GDP growth. The authors argue that civic participation generates knowledge externalities, lowers transaction costs, and provides better enforcement. In addition, consistent with the data from Russia, trust in public institutions is positively correlated with growth. The analyses also confirm the notion that higher levels of civic participation lead to higher levels of public trust (often called generalised trust). However, since both of these results are positively correlated with GDP growth, it is difficult to determine the causality between the three variables. Owing to the lack of variables that can be used to measure the informal dimension of social capital consisting in interpersonal networks, the first comparative analysis of social capital in transforming societies examines only its formal aspects.

More recently, Fidrmuc and Gerxhani [2005] compared the stock of social capital in the older European Union member countries with the new member countries, claiming that social capital defined as a public good (i.e. leading to economic growth) can be achieved through economic and institutional development in transforming countries. Using six indicators of civic participation, social networks, and

1 The World Values Survey - WVS, the New Democracy Barometer - NDB, and EBRD's Business Environment Survey BEEPS. 
altruism, the data show that such determinants of social capital as education and income tend to have similar effects on civic participation and access to social networks in both of these regions. However, occupation and employment status show more profound differences between these two regions. In the new EU member countries people in white-collar jobs tend to show a higher level of civic participation, and thus also access to social networks, than those in older EU member countries.

Finally, the role of the informal network dimension of social capital raises fundamental questions about measuring instrumental actions (gaining resources) and expressive actions (maintaining resources). There are three measurement instruments that capture resource collections in exchange networks that, to the best of our knowledge, have not been used in transforming societies. First, based on a theory of social resources, a 'name generator' instrument provides informative data describing informal relationships and resources ${ }^{2}$ [Van Der Gaag and Snijders 2004]. Second, a 'position generator' measures access to network members' occupations, which are traditionally associated with occupational prestige. The access is measured by analysing the strength of the role of informal networks (i.e. family members, friends, acquaintances $)^{3}$ in access to occupations. That measurement technique is useful mainly for cross-population comparisons related to prestige [Van Der Gaag and Snijders 2004]. However, social relationships are more systematically measured with a 'resource generator' instrument. This instrument asks about access to specific social resources covering several domains of life. ${ }^{4}$ The focus on possessing or mastering particular skills is suitable primarily for within-population comparisons [Van Der Gaag and Snijders 2005]. While all of these instruments put emphasis on the strength of the informal exchange network dimension of social capital, their major limitation is the focus on the general population only.

\section{What should be the next step?}

In order to proceed further in the analysis of social capital and its role in social and economic development so as to overcome the existing problems, especially with regard to its measurement, the effort should concentrate on four issues:

\footnotetext{
2 The measurement is based on asking subjects questions such as whom do you contact for help; whom do you contact to obtain help to find a home; whom do you contact to obtain help with small jobs, etc.

3 The measurement is based on asking subjects whether he/she knows a family member in a particular occupation. If not, then the subjects are asked about a friend in that occupation. If not, then the subjects are asked about knowing an acquaintance in that occupation.

4 The measurement is based on providing subjects with a number of skills and resources and asking him/her if he/she knows a family member who possesses the given resource or masters the given skill. If not, then the subjects are asked if they know a friend or acquaintance who possesses the given resource or masters the given skill. The examples are: Do you know anyone who owns a car, can work with a PC, knows a lot about governmental regulations, has good contacts with a newspaper, radio or TV station, etc.
} 
1. tracing the use of potentially suitable indicators of various dimensions of social capital in existing comparative surveys;

2. creating scales that represent distinct dimensions of social capital and assessing their reliability in different social and cultural systems;

3. analysing the relationships between the main dimensions of social capital in different systems;

4. assessing relationships between the main dimensions of social capital and other relevant variables (e.g. political efficacy and other relevant political attitudes, a person's position in the class structure and social stratification, etc.).

As for post-communist countries, the research agenda should begin with an attempt to develop measures of social capital that make it possible to assess the degree and effects of the involvement of 'weak social ties' (networks in Bourdieu's sense) in shaping people's life-chances (job and career mobility, access to highly valued resources, etc.). To achieve this goal, two sets of indicators should be developed:

a) indicators of social capital stemming primarily from a current and/or past position in the social and power structures (positional social capital);

b) indicators of a person's active involvement in building networks based on the mutual recognition of usefulness and various kind of exchanges.

Research in this direction is not yet very well developed, though some indicators have already been used to measure this particular dimension of social capital. For example, in order to assess the feasibility of measuring a person's participation in networks based on informal exchanges (in Bourdieu's definition) a set of questions was developed and used in the Social Stratification Survey carried out in 1993 in five post-communist countries: Bulgaria, Czech Republic, Hungary, Poland, Russia and Slovakia (see the Appendix for the wording of the questions PRVHLP, GETHLP and IMPORT). ${ }^{5}$

Variables created from these questions proved the existence of a latent variable representing relevant dimensions of social capital strongly related to one's position in the social structure (social status, prestige, esteem) and political capital (party membership, political participation). At the same time, social capital assessed by this particular measurement strategy proved to be a significant predictor of the respondents' adaptive strategies during the first years of transition and, consequently, also the change in the level of their income between 1989 and 1993 [Matějů and Lim 1995]. Matějů and Lim conclude that social capital played a significant role in improving life-chances within the 'bureaucratically co-ordinated' segment of the labour market and particularly in the private sector. They also show that the convertibility of social capital has been an important element in the transformation of the social structure because it is a significant instigator of both functional advancement and a person's entry into the entrepreneurial class. Therefore,

5 The questions assessing the subjective evaluation of a respondent's involvement in exchange networks were ultimately posed only in the Czech Republic and Slovakia. 
the convertibility of social capital considerably increased the chance of former cadres maintaining their income privileges [Matějů and Lim 1995].

Based on the theoretical discussion above, we propose the following hypotheses to be further elaborated and tested, though - owing to some limitations that will be discussed further on - we cannot address all of them empirically at this stage and in this paper:

H1: Social capital defined as generalised trust and social capital defined as a person's involvement in mutually beneficial exchanges are two distinct dimensions of social capital that cannot be amalgamated under a single measure of general social capital. ${ }^{6}$

$\mathrm{H} 2$ : There is more variation between countries with regard to the degree of social capital defined as generalised trust than with regard to social capital defined as a person's involvement in mutually beneficial exchanges. ${ }^{7}$

H3: Social capital defined as generalised trust is spread out evenly among different social groups while social capital defined as a person's involvement shows significant variation among groups defined by stratification-relevant variables (education, socio-economic status, prestige, and social class). We expect that social capital based on mutually beneficial exchanges is sensitive to such attributes of an individual that are or can become an asset in the exchanges. ${ }^{8}$

\section{Data and the measurement model}

This analysis of the two dimensions of social capital is based on the data from Social Network Survey (SNS) carried out in the Czech Republic in 2001 under the International Social Survey Programme (ISSP). A sample of 1200 randomly selected respondents represents the Czech adult population aged 18 years and older. ${ }^{9}$

Our initial goal was to develop a measurement model that would confirm (or reject) the existence of two separate dimensions of social capital (hypothesis H1). In order to achieve this objective, we focused on six questions, three of them assessing the degree of generalised trust and the remaining three questions asking respondents about their participation in informal networks based on mutually beneficial

\footnotetext{
${ }^{6}$ In this article, hypothesis $\mathrm{H} 1$ will be tested on the Czech data.

7 In this article we can only provide preliminary evidence supporting the assumption that social capital defined as generalised trust shows significant cross-national variation among countries.

${ }^{8}$ Like hypothesis H1, this hypothesis will also be tested only on the Czech data.

9 The data set included a series of weights that are necessary for descriptive purposes but are less important for research utilising multivariate designs. In order to assess the effects of weights, we performed the main analysis twice - with and without weights - and found that the results did not differ substantially. For this reason, we present the results using unweighted data.
} 
Table 2. First order correlations among indicators of social capital

\begin{tabular}{lllcccc}
\hline & TRUST1 & TRUST2 & TRUST3 & EXNET1 & EXNET2 & EXNET3 \\
\hline TRUST1 & 1 & .129 & .319 & -.034 & .096 & -.009 \\
TRUST2 & .000 & 1 & .214 & .009 & .108 & .154 \\
TRUST3 & .000 & .000 & 1 & -.062 & .076 & -.038 \\
EXNET1 & .249 & .761 & .036 & 1 & .347 & .252 \\
EXNET2 & .001 & .000 & .010 & .000 & 1 & .448 \\
EXNET3 & .755 & .000 & .199 & .000 & .000 & 1 \\
\hline
\end{tabular}

Upper diagonal cells: Pearson correlation; lower diagonal cells: Significance (2-tailed)

Figure 1. Measurement model for social capital - a single factor model (standardised solution)

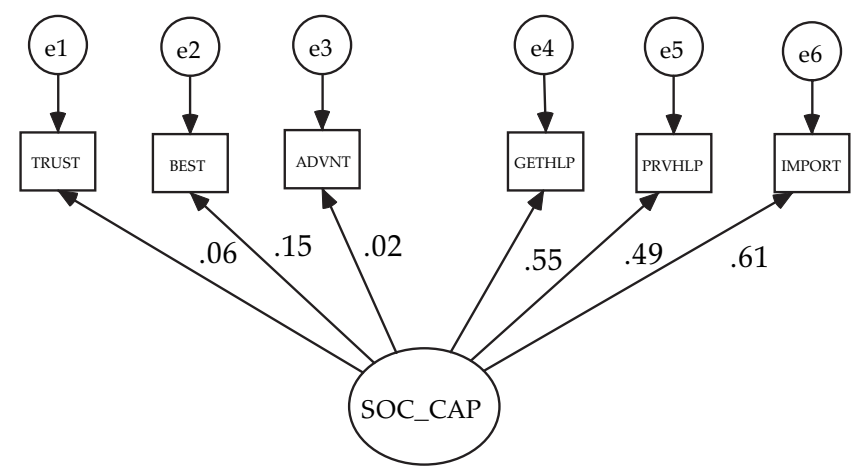

Chi-square $=214.294(9 \mathrm{df}), \mathrm{p}=.000$

$\mathrm{GFI}=.937, \mathrm{BIC}=319.918, \mathrm{RMSEA}=.144$

exchanges. ${ }^{10}$ The wording of the questions and the distributions of answers are shown in Appendix 1. The answers to these six questions were recoded so that the higher the value the higher the level of trust or participation (in practical terms it meant reversing the scales of the variables BEST and IMPORT).

The correlation matrix in Table 2 presents some interesting results from the initial analyses. The variables representing trust (TRUST1, TRUST2, TRUST3) and the variables indicating the participation in informal networks based on mutually

${ }_{10}$ This set of questions was taken from a research project conducted in 1994 by the Department of Social Stratification at the Institute of Sociology, Academy of Sciences of the Czech Republic. 


\section{Figure 2. Measurement model for social capital - two factors solution}

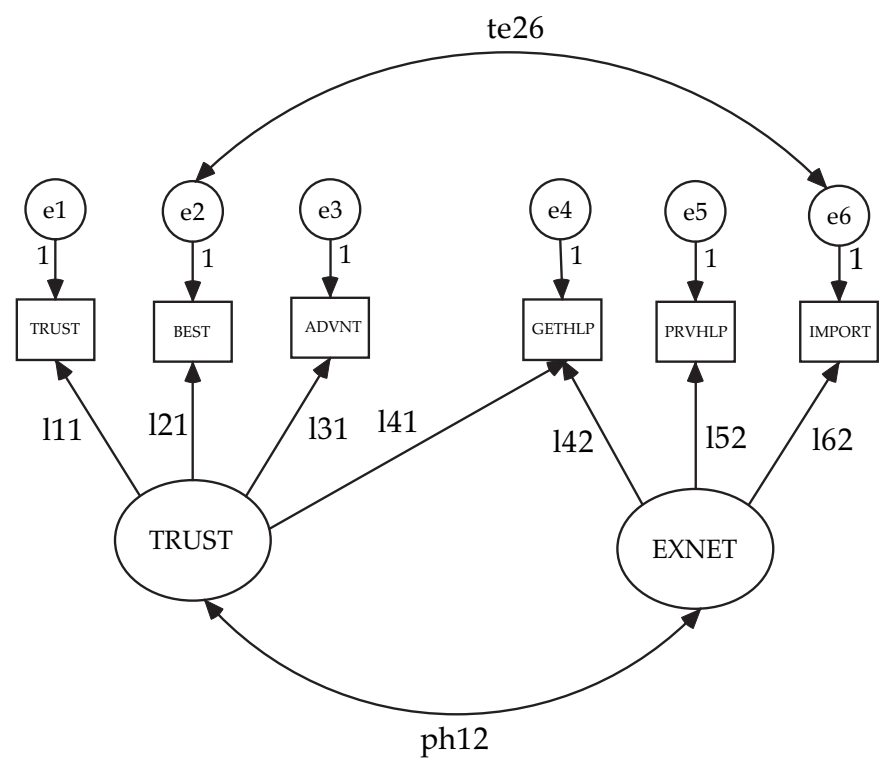

beneficial exchanges (EXNET1, EXNET2, EXNET3) proved the existence of two separate latent variables; thus two conceptually distinct forms of social capital served as the basis for our first structural equation model (Figure 1).

The counter-hypothesis about the existence of only one factor (one dimension) of social capital was tested using confirmatory factor analysis. The results displayed in Figure 1 show that the one-factor hypothesis had to be rejected because the model assuming only one underlying dimension fitted very poorly (chi-square $=214.29$, $\mathrm{df}=9) .{ }^{11}$ Owing to the unsatisfactory fit, the one-factor model was replaced with subsequent models, which contained two latent independent variables representing two dimensions of social capital: TRUST, defined as generalised trust between members of society, and EXNET, defined as participation in mutually beneficial exchange networks (Figure 2).

Table 3 displays the statistics of fit and the individual parameters of three different models based on a two-factor solution. The first two-factor model (M1) was tested without correlations between measurement errors, without correlations between factors, and without factor loadings across dimensions (Table 3, M1). The test of Model 1 resulted in substantial improvements in the fit of the model when compared to the one-factor model, but its values were not satisfactory (chi-square $=49.7, \mathrm{df}=9$ ).

11 To test different models of measurement, we applied confirmatory factor analyses, for which we utilised the Analysis of Moment Structure (AMOS) software, version 4.0. 
Table 3. Statistics of fit and parameters of two factor models (M1, M2 and M3)

\begin{tabular}{|c|c|c|c|c|c|c|c|c|c|}
\hline \multirow{3}{*}{ Parameter / index } & \multicolumn{9}{|c|}{ Model } \\
\hline & \multicolumn{3}{|c|}{ M1 } & \multicolumn{3}{|c|}{ M2 } & \multicolumn{3}{|c|}{ M3 } \\
\hline & Estim. & S.E. & Stand. & Estim. & S.E. & Stand. & Estim. & S.E. & Stand. \\
\hline $1_{11}$ (trust - TRUST) & 1.807 & 0.316 & 0.505 & 1.849 & 0.316 & 0.518 & 1.822 & 0.307 & 0.526 \\
\hline$l_{21}($ best - TRUST) & $1^{*}$ & - & 0.276 & $1^{*}$ & - & 0.276 & $1^{*}$ & - & 0.285 \\
\hline $1_{31}($ advnt - TRUST) & 2.477 & 0.539 & 0.668 & 2.412 & 0.461 & 0.651 & 2.295 & 0.428 & 0.640 \\
\hline $1_{42}($ gethlp - EXNET) & 1.125 & 0.129 & 0.546 & 1.171 & 0.133 & 0.568 & 1.149 & 0.130 & 0.556 \\
\hline $1_{52}($ prvhlp - EXNET) & $1^{*}$ & - & 0.511 & $1^{*}$ & - & 0.511 & $1^{*}$ & - & 0.510 \\
\hline $1_{62}$ (import- EXNET) & 1.157 & 0.137 & 0.598 & 1.140 & 0.131 & 0.590 & 1.146 & 0.133 & 0.592 \\
\hline $1_{41}($ gethlp - TRUST) & $0^{*}$ & - & - & 0.862 & 0.231 & 0.199 & 0.718 & 0.191 & 0.170 \\
\hline $\mathrm{te}_{26}(\mathrm{e} 2-\mathrm{e} 6)$ & $0^{*}$ & - & - & 0.137 & 0.027 & 0.183 & 0.132 & 0.027 & 0.177 \\
\hline \multirow[t]{2}{*}{$\mathrm{ph}_{12}($ TRUST - EXNET) } & $0^{*}$ & - & - & -0.013 & 0.008 & -0.095 & $0^{*}$ & - & - \\
\hline & \multicolumn{9}{|c|}{ Statistic of fit } \\
\hline Chisq & \multicolumn{3}{|c|}{49.7} & \multicolumn{3}{|c|}{3.556} & \multicolumn{3}{|c|}{6.031} \\
\hline $\mathrm{df}$ & \multicolumn{3}{|c|}{9} & \multicolumn{3}{|c|}{6} & \multicolumn{3}{|c|}{7} \\
\hline $\mathrm{p}$ & \multicolumn{3}{|c|}{0.000} & \multicolumn{3}{|c|}{0.737} & \multicolumn{3}{|c|}{0.536} \\
\hline GFI & \multicolumn{3}{|c|}{.985} & \multicolumn{3}{|c|}{.999} & \multicolumn{3}{|c|}{.998} \\
\hline RMSEA & \multicolumn{3}{|c|}{0.064} & \multicolumn{3}{|c|}{.000} & \multicolumn{3}{|c|}{.000} \\
\hline $\mathrm{BIC}^{*}$ & \multicolumn{3}{|c|}{-14.11} & \multicolumn{3}{|c|}{-38.98} & \multicolumn{3}{|c|}{-43.60} \\
\hline
\end{tabular}

* For BIC we applied the original formula (see e.g. Knoke and Bohrnstedt [1994]).

Model 2 (Table 3, M2) was therefore tested with correlations between measurement errors $\left(\mathrm{te}_{26}\right)$, correlations between factors $\left(\mathrm{ph}_{12}\right)$, and with one-factor loading across dimensions $\left(l_{41}\right)$. This model resulted in a very good fit (chi-square $=3.6$, $\mathrm{df}=6$ ). Since the correlation between the two latent variables of TRUST and EXNET in Model 2 is not statistically significant $(\mathrm{r}=-0.10)$, we decided to constrain a covariance parameter by changing the correlation between these variables to zero (Table 3, $\mathrm{M} 3$ ). The constrained parameter improved our model (chi-square $=3.6, \mathrm{df}=7$ ) and increased the BIC index, which is sensitive to parsimony. The goodness-of-fit index (GFI) was .99 and the root mean square of error approximation (RMSEA) was .00. These values indicate a good model-to-data fit. Therefore, Model M3 was accepted as the best measurement model, confirming our hypothesis that TRUST and EXNET are two separate dimensions of social capital. The factor scores from this model were consequently used to calculate latent dimensions of the social capital TRUST and EXNET.

Figure 3, which shows the means and 95\% confidence intervals for the variable TRUST by country, confirms the part of our hypothesis (H1) claiming that social capital defined as generalised trust shows significant cross-national variation among 
Figure 3. Means and $95 \%$ confidence intervals for the variable TRUST by country

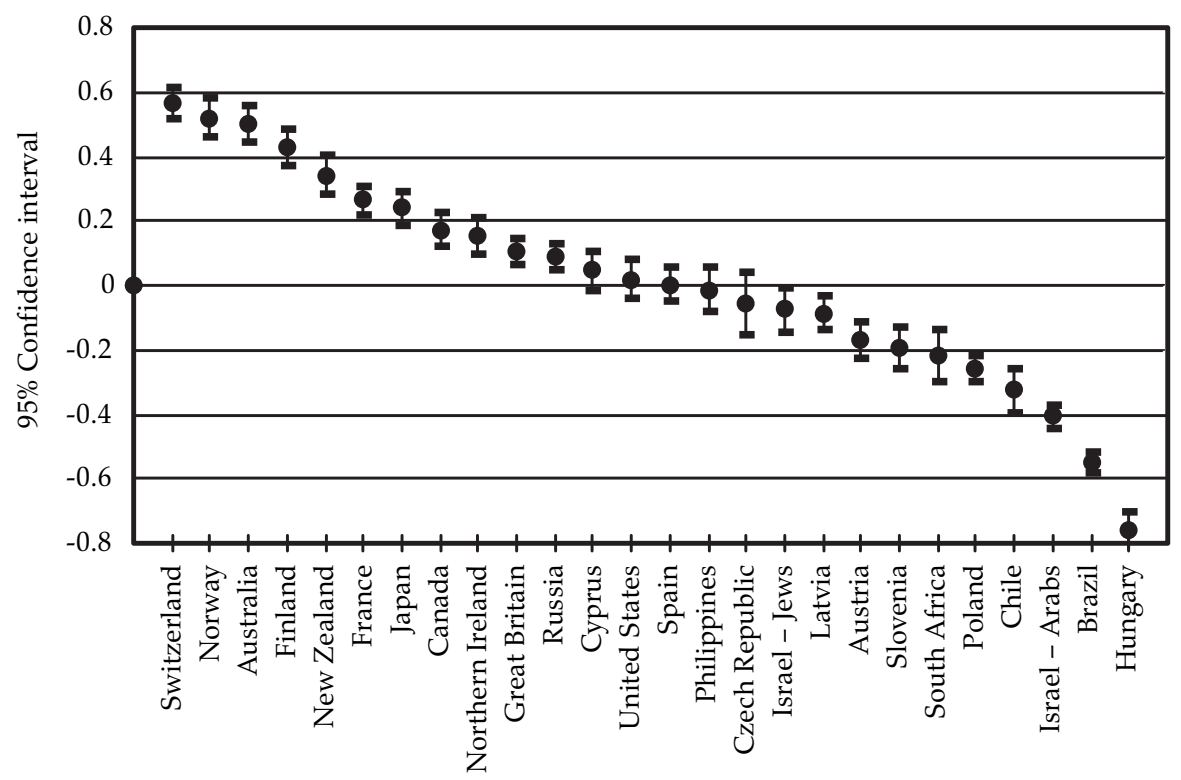

Table 4. Analysis of variance of the variables TRUST and EXNET (Czech Republic)

\begin{tabular}{lccc}
\hline & Mean Square & F & Sig. \\
\hline TRUST & & & \\
EDUC & 0.023 & 0.560 & 0.642 \\
EGP CLASS & 0.184 & 4.672 & 0.000 \\
PRESTIGE (quint.) & 0.042 & 1.024 & 0.394 \\
ISEI (quint.) & 0.109 & 2.687 & 0.030 \\
& & & \\
EXNET & & & \\
EDUC & 4.136 & 27.140 & 0.000 \\
EGP CLASS & 2.254 & 14.963 & 0.000 \\
PRESTIGE (quint.) & 1.858 & 11.818 & 0.000 \\
ISEI (quint.) & 1.632 & 10.317 & 0.000 \\
\hline
\end{tabular}


Figure 4. Means and 95\% confidence intervals for the variables TRUST and EXNET by respondent's education (Czech Republic)

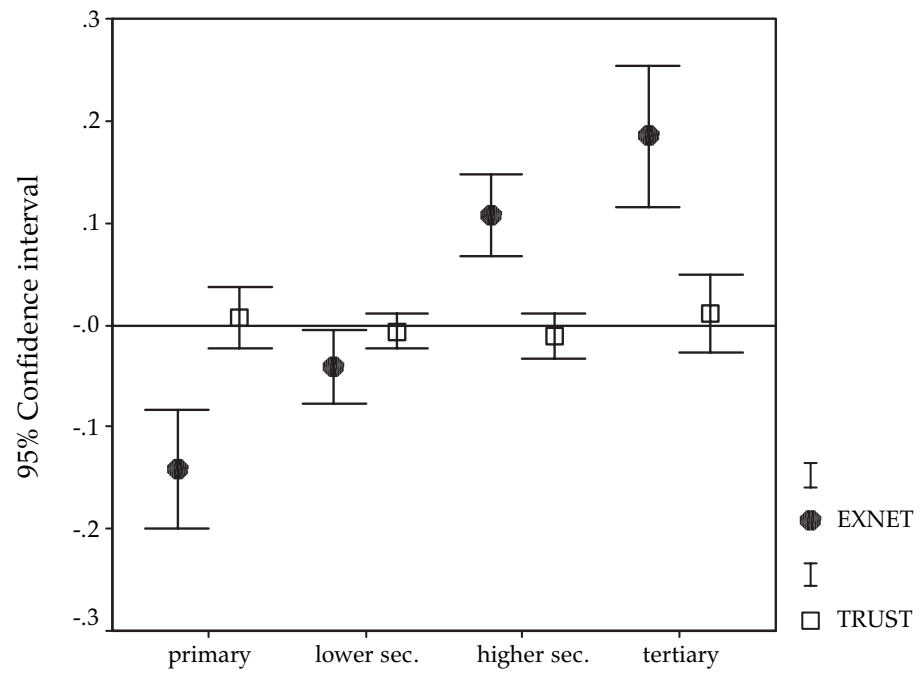

Respondent's education

countries. In Switzerland, Norway, Australia, Finland, and New Zealand, the values for the variable TRUST are significantly above the average, in contrast to countries, such as South Africa, Poland, Chile, and Hungary where the value for the same variable TRUST is significantly below the average (social capital stemming from trust in these countries is quite low). The Czech Republic, along with Spain, Latvia, and the United States, shows an average score. Owing to the fact that no other countries, except the Czech Republic, posed questions about participation in exchange networks, the extent of the differences between countries in this respect cannot be assessed.

The subsequent hypothesis (H3), stating that the impact of stratification variables on the two dimensions of social capital (TRUST and EXNET) is different, are addressed in Table 4 . The results of the analysis of variance of the variables TRUST and EXNET in categories defined by education (EDUC), social class (EGP), prestige (PRESTIGE), and socio-economic status (ISEI) confirm that the variation of the variable TRUST among categories of these variables is much smaller than the variation of the variable EXNET across the same groups. The effects of education and prestige on TRUST are not statistically significant $(\mathrm{F}=4.67$ and $\mathrm{F}=2.69$ respectively) in comparison to the influence of these variables on EXNET $(F=27.14$ and $F=14.96$ respectively).

Figures 4 through 7 illustrate in detail the different effects of the stratification variables on TRUST and EXNET. Figure 4, which shows the means and 95\% confi- 
Figure 5. Means and 95\% confidence intervals for the variables TRUST and EXNET by quintiles of the International Index of Socio-economic Status (Czech Republic)

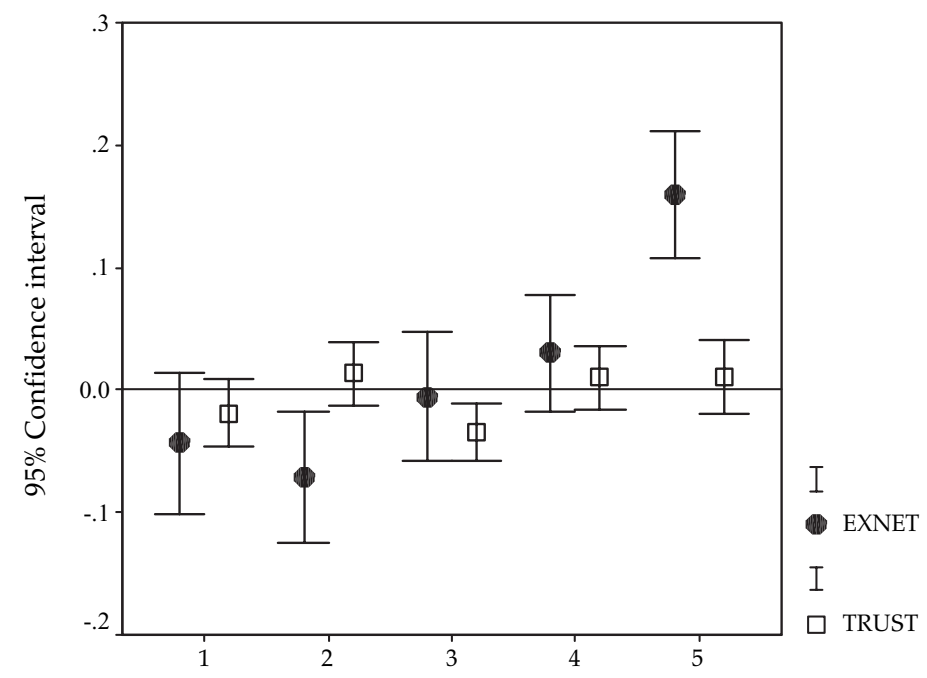

Quintiles of socio-economic index score

Figure 6. Means and 95\% confidence intervals for variables TRUST and EXNET by quintiles of the international index of prestige (Czech Republic)

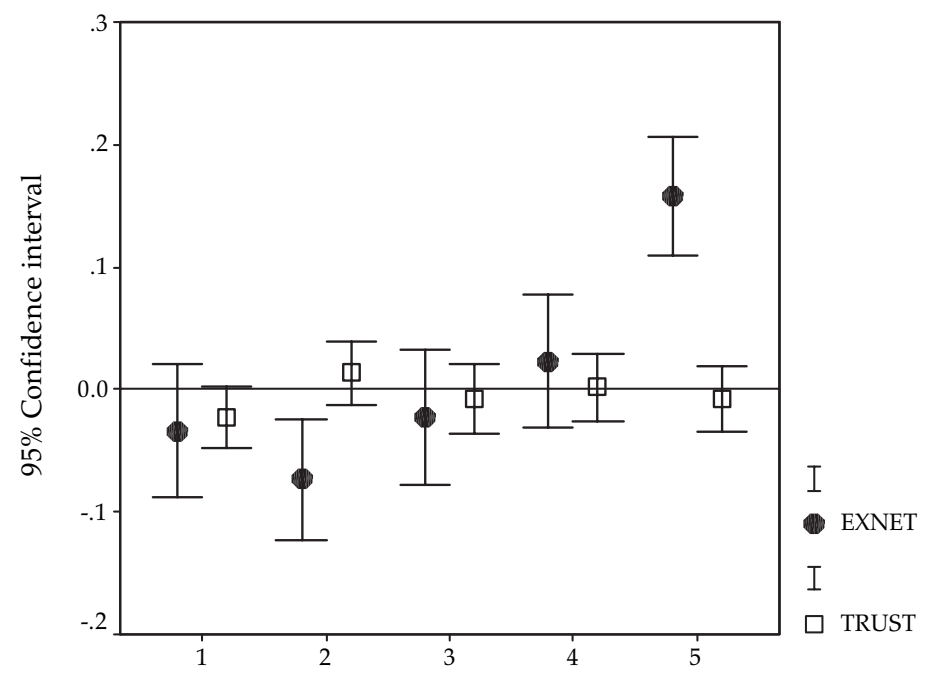

Quintiles of prestige score 
Figure 7. Means and 95\% confidence intervals for the variables TRUST and EXNET by respondent's social class (Czech Republic)

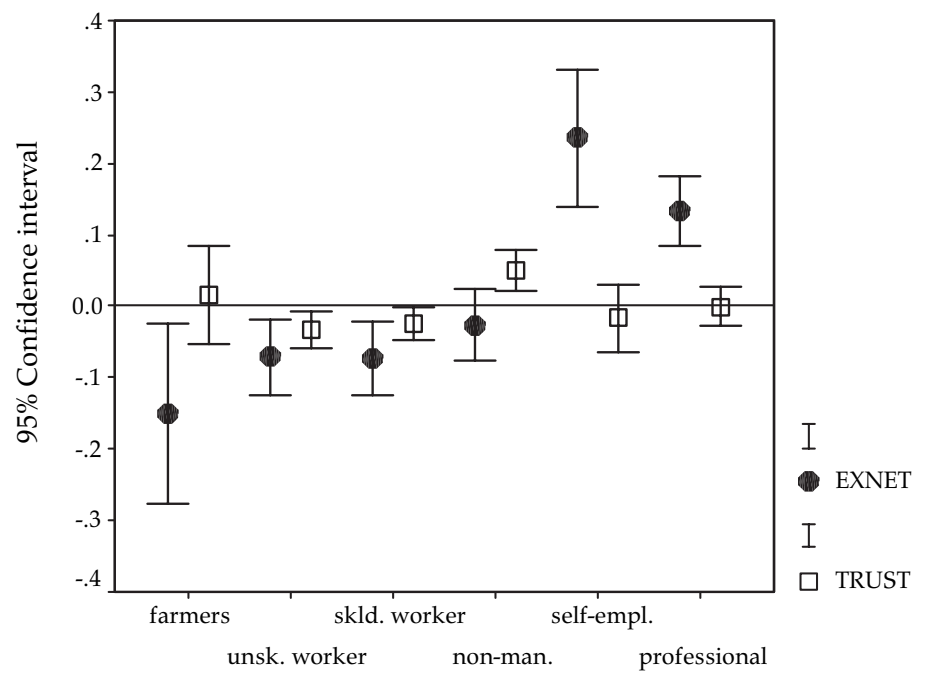

Respondent's EGP class

dence intervals for TRUST and EXNET for groups defined by a respondent's education in the Czech Republic, convincingly confirms our hypotheses about the role of education in participation in exchange networks; the higher the education level of the respondent, the greater the participation in exchange networks. In contrast, the achieved level of education shows practically no effects on the level of generalised trust (TRUST).

To examine the effects of socio-economic status ${ }^{12}$ on the variables TRUST and EXNET, we divided the score of ISEI into quintiles. The results, displayed in Table 4 (analysis of variance) and in Figure 5, support the hypothesis that TRUST is only weakly linked to socio-economic status, or in other words, it is more or less evenly dispersed across categories of socio-economic status, whereas the participation in exchange networks is highly associated with a person's socio-economic status.

Similarly, Figure 6 presents the means and 95\% confidence intervals of the variables TRUST and EXNET for groups defined as quintiles of prestige, measured using the International Standard Index of Occupational Prestige [Treiman 1977]. In agreement with our hypothesis, the higher the respondent's prestige, the greater the participation in exchange networks. It is worth noticing particularly the position of

12 Socio-economic status is measured using the Standard International Socio-Economic Index of Occupational Status developed by Ganzeboom, De Graaf and Treiman [1992]. 
the highest prestige group (fifth quintile), which is far above the other groups. These results strongly support the assumption that high prestige (particularly in those based on mutually beneficial exchanges) is a highly valued 'symbolic asset' in social networks, one through which people are able to exert their influence in social relations and, in exchange, receive a support or asset they are seeking.

And finally, Figure 7 shows the effects of social class on TRUST and EXNET. From Figure 7 it is apparent that a respondent's social class has a greater impact on EXNET than on TRUST. TRUST is equally distributed among the members of different social classes. ${ }^{13}$ There are some interesting findings pertaining to social class and its effects on participation in exchange networks. For instance, the self-employed respondents participate in these networks the most, even more so than professionals; that deserves attention in future research. Furthermore, there tends to be no, or very little, difference in participation in exchange networks between the working class, the lower class and the middle class: unskilled, skilled, and non-manual workers show almost the same low level of participation.

To sum up, we attempted to develop a measurement model for the two distinct dimensions of the construct of social capital, one defined primarily as an attribute of societies based on generalised trust, the other defined as the capacity of an individual to participate in informal networks based on mutually beneficial exchanges. Using the confirmatory factor analysis, we tested and confirmed the proposed model of social capital. We proceeded by testing the hypotheses that social capital defined as trust was only weakly linked to social stratification variables of education, socio-economic status, prestige, and social class, and thus the presence (or absence) of trust is fairly evenly distributed among social groups, while social capital defined as person's involvement in mutually beneficial exchanges showed significant variations among groups defined by relevant stratification variables. Our hypotheses were confirmed. Owing to the lack of comparative international data on participation in exchange networks, we were not able to test the hypotheses about the extent of differences between countries regarding the two dimensions of social capital. Nevertheless, the existence of such a difference was clearly confirmed.

\section{Conclusion}

Research on social capital is in its early stages and much work still needs to be done on designing proper instruments for its measurement. There is no doubt, however, that the research already conducted has proven the existence of two important characteristics of social capital: 1) it has the capacity to contribute to explaining economic growth (especially in advanced countries), and 2) it has the capacity to shed light on particular determinants of life-success (particularly in transforming societies).

13 We applied the EGP class schema developed by Erikson, Goldthorpe and Portocarero (see e.g. Erikson and Goldthorpe [1992]). 
The problem of transforming (post-communist) societies basically lies in the contrary effects of the two forms of social capital. Social capital in Putnam's interpretation is essential and necessary for social co-operation, for it allows the emerging market to function. As George Kolankiewicz puts it: 'It is essential as the noncontractual element in the contract when the legal underpinnings to the market are far from completed or remain (necessarily) ambiguous. Trust provides the element of predictability which is absent given the low stock of formal rationality in the system' [Kolankiewicz 1996: 447]. Paradoxically, the potential of this particular form of social capital derived from generalised trust seems to be somewhat weak in the post-communist countries. By contrast, the 'strength of weak ties' [Granowetter 1973], or, in other words, social capital that derives from informal networks and exchanges, thereby allowing people to develop specific coping strategies that facilitate the accumulation of social capital and form class structure, may actually hinder - at least temporarily - the effective functioning of market mechanisms and, consequently, economic growth.

This is why, particularly in transforming societies, it will be important to develop research strategies that take into consideration the particular socio-economic and historical context of these countries; only by doing so we can significantly improve the measurement of both forms of social capital. The findings from our research, though it is in many respects rather in its initial stage, implicitly call for more effort in conceptualising social capital and for testing various strategies of its measurement.

PETR MATĚJU is a professor of sociology and chair of the Department of the Sociology of Education and Stratification at the Institute of Sociology, Academy of Sciences of the Czech Republic. His major research interests are social stratification and mobility, inequality and equity in education. He has published a number of articles on social transformation in East Central Europe and co-edited three books: Ten Years of Rebuilding Capitalism, Czech Society after 1989 (published in 1998 in English), Inequality - Justice - Politics (in Czech, published in 2000), and Unequal Chances for Education (in Czech, published in 2006).

ANNA VITÁSKOVÁ works as a researcher in the Department of the Sociology of Education and Stratification at the Institute of Sociology, Academy of Sciences of the Czech Republic. She holds a PhD in educational policy and administration from the University of Minnesota, USA. She is the author of several articles and chapters in books dealing with the role of large public universities in the development and production of intangible human capital. 


\section{References}

Bourdieu, P. 1985. 'Forms of Capital.' Pp. 241-258 in Handbook of Theory and Research in the Sociology of Education, edited by J Richardson. New York: Greenwood Press.

Coleman, J. 1987. 'Norms as Social Capital.' Pp. 133-155 in Economic Imperialism: The Economic Method Applied outside the Field of Economics, edited by Gerard Radnitzky and Peter Bernholz. New York: Paragon House Publishers.

Coleman, J. 1988. 'Social Capital and the Creation of Human Capital. American Journal of Sociology, 94 (supplement): 94-120.

Erikson R. and J.H. Goldthorpe, 1992. The Constant Flux: A Study of Class Mobility in Industrial Societies. Oxford: Clarendon.

Eyal, G., I. Szelényi and E. Townsley. 1998. Making Capitalism Without Capitalists. The New Ruling Elites in Eastern Europe. Verso, London, New York.

Fidrmuc, J. and K. Gerxhami. 2005. 'Formation of Social Capital in Central and Eastern Europe: Understanding the Gap vis-à-vis Developed Countries.' CEPR Discussion Paper No. 5068, Centre for Economic Policy Research, London.

Ganzeboom, H. B. G., P. M. De Graaf and D. J. Treiman. 1992. 'A Standard International Socio-Economic Index of Occupational Status.' Social Science Research 21: 1-56.

Granovetter, M. 1973. 'The Strength of Weak Ties.' American Journal of Sociology 78: 1360-80.

Grief, A. 1994. 'Cultural Beliefs and the Organization of Society: A Historical and Theoretical Reflection on Collectivist and Individual Societies.' Journal of Political Economy 102: 912-945.

Hanley, E., P. Matějů, K. Vlachová and J. Krejčí. 'The Making of Post-Communist Elites in Eastern Europe, Institute of Sociology.' Working Papers, 4/1998.

Kolankiewicz, G. 1996. 'Social Capital and Social Change.' British Journal of Sociology 47 (3): 427-441.

Kunioka T. and G. Wolker, 1999. 'In (a) Democracy We Trust: Social and Economic Determinants of Support for Democratic Procedures in Central and Eastern Europe.' European Journal of Political Economy 28: 577-596.

Lin N. and M. Dumin 1986. 'Access to Occupations through Social Ties.' Social Networks 8: 365-385.

Loury, G. (ed.). 1977. A Dynamic Theory of Racial Income Differences. Women, Minorities, and Employment Discrimination. Lexington, Mass., Lexington Books.

Matějů, P. and N. Lim. 1995. 'Who Has Gotten ahead after the Fall of Communism? The Case of the Czech Republic.' Czech Sociological Review 3: 117-136.

Narayan, D. 1995. 'Designing Community-Based Development.' Social Development Paper 7. World Bank, Environmentally and Socially Sustainable Development Network, Washington, D.C. Processed.

Narayan, D. 1997. 'Voices of the Poor: Poverty and Social Capital in Tanzania.' Environmentally Sustainable Development Monograph 20. World Bank, Washington, D.C.

Narayan, D. 1998. 'Social Capital Survey in Ghana-Preliminary Results.' World Bank, Poverty Reduction and Economic Management Network, Washington, D.C. Processed.

Narayan, D. 1999. 'Bonds and Bridges: Social Capital and Poverty.' Policy Research Working Paper 2167. World Bank, Poverty Reduction and Economic Management Network, Washington, D.C. Processed.

Narayan, D. and M. Cassidy. 1999. 'A Dimensional Approach to Measuring Social Capital: Development and Validation of a Social Capital Inventory.' World Bank, Poverty Reduction and Economic Management Network, Washington, D.C. Processed.

O'Brian, D. 1998. 'Social Capital and Community Development in Rural Russia.' The World Bank, Working Papers. 1998. 
OECD. 2000. Literacy in the Information Age. Final Report of the International Adult Literacy Survey (SIALS). Paris, OECD.

OECD. 2001a. Knowledge and Skills for Life. First Results from PISA 2000. OECD, Paris, 2001.

OECD. 2001b. The Well-Being of Nations. The Role of Human and Social Capital. OECD, Paris, 2001.

Paldam, M. and G. T. Svendsen. 2001. 'Missing Social Capital and the Transition in Eastern Europe.' Journal for Institutional Innovation, Development, and Transition 5: 21-34.

Portes, A. 1998. 'Social Capital: Its Origins and Applications in Contemporary Sociology.' Annual Review of Sociology 24: 1-24.

Putnam, R. 1993. Making Democracy Work: Civic Traditions in Modern Italy. Princeton, N.J.: Princeton University Press.

Putnam, R. 1995. 'Tuning In, Tuning Out: The Strange Disappearance of Social Capital in America.' PS: Political Science and Politics (December): 664-83.

Putnam, R. 2000a. Bowling Alone: The Collapse and Revival of American Community. New York: Simon and Schuster.

Putnam, R. 2000b. 'Considering the Empirical Evidence for the Economic Impact and the Broad Social returns to Human and Social Capital.' Paper presented at OECD conference 2000.

Raiser, M. 1999. 'Trust in Transition.' EBRD Working Paper, No. 39, London.

Raiser, M., C. Haerpfer, T. Nowotny and C. Wallace. 2001. Social Capital in Transition Countries: A First Look at the Evidence. EBRD Working Paper, 2001.

Rose, R. 1998a. 'Getting Things Done with Social Capital: New Russia Barometer VII.' University of Strathclyde Studies in Public Policy, No. 303.

Rose, R. 1998b. 'Getting Things Done in an Anti-Modern Society: Social Capital Networks in Russia.' Social Capital Initiative Working Paper 8. World Bank, Social Development Department, Washington, D.C. Processed.

Rose, R., W. Mishler and C. Haerpfer. 1997. 'Getting Real, Social Capital in PostCommunist Societies.' University of Strathclyde, Studies in Public Policy, No. 278.

Rose, R., W. Mishler, and C. Haerpfer. 1998. Democracy and Its Alternatives: Testing the Churchill Hypothesis in Post-Communist Countries. Baltimore: Johns Hopkins University Press.

Stone, W. 2001. 'Measuring Social Capital: Towards a Theoretically Informed Measurement Framework for Researching Social Capital in Family and Community Life.' Research paper \# 24. Australian Institute of Family Studies.

Treiman, D.J. 1977. Occupational Prestige in Comparative Perspective. New York: Academic Press.

Van Der Gaag, M.P.J. and T.A.B. Snijders. 2004. 'Proposals for the Measurement of Individual Social Capital.' Pp. 199-218 in Creation and Returns of Social Capital, edited by H.D. Flap and B. Volker. London: Routledge.

Van Der Gaag, M.P.J. and T.A.B. Snijders. 2005. 'The Resource Generator: Social capital Quantification with Concrete Item.' Social Networks 27: 1-29.

Woolcock, M. 1998. 'Social Capital and Economic Development: Toward a Theoretical Synthesis and Policy Framework.' Theory and Society 27 (2): 151-208.

Woolcock, M. 1999. 'Learning from Failures in Microfinance: What Unsuccessful Cases Tell Us about How Group-Based Programs Work.' American Journal of Economics and Sociology 58 (1): 17-42.

Woolcock, M. 2000. 'Managing Risk, Shocks, and Opportunities in Developing Economies: The Role of Social Capital.' Pp. 225-249 in Dimensions of Development, edited by Gustav Ranis. New Haven, Conn.: Yale Center for International and Area Studies.

Woolcock, M. and D. Narayan. 2000. 'Social Capital: Implications for Development Theory, Research. and Policy.' The World Bank Research Observer; Washington; Aug. 2000. 


\section{Appendix: Distributions of variables}

TRUST: There are only a few people I can trust completely

1. Agree strongly

2. Agree

3. Neither agree or disagree

4. Disagree

5. Disagree strongly

BEST: Most of the time you can be sure that other people want the best for you

1. Agree strongly

2. Agree

3. Neither agree or disagree

4. Disagree

5. Disagree strongly

Total

ADVNT: If you are not careful other people will take advantage of you

1. Agree strongly

2. Agree

3. Neither agree or disagree

4. Disagree

5. Disagree strongly

Total

PRVHLP: How often, because of your job, the office you hold, or contacts you have, do other people (relatives, friends, acquaintances) turn to you to help them solve some problems, cope with difficult situations, or apply your influence for their benefit?

1. Never

2. Seldom

3. Occasionally

4. Quite often

5. Very often

Total 
GETHLP: And what about you? When you are in a difficult situation, do you think there are people who could intervene on your behalf?

1. No, nobody

2. Very few

3. Some

4. Quite a few

5 . Very many

Total

IMPORT: How important a role do useful contacts play in your life?

1. Essential

2. Very important

9.7

3. Fairly important

28.2

4. Not very important

5. Not important at all 13.7 Total 100.0 